\title{
HISTOMORPOLOGY OF PAPILLARY THYROID CARCINOMA AND FOLLICULAR THYROID CARCINOMA IN THE LABORATORY OF ANATOMIC PATHOLOGY UNIT RSUP H.ADAM MALIK MEDAN 2015-2019
}

${ }^{1}$ Roy Herbon Sinambela, ${ }^{2}$ Lidya Imelda Laksmi, ${ }^{3}$ Joko S Lukito, ${ }^{4}$ Delyuzar, ${ }^{5}$ T.Ibnu Alferraly

Departement of Anatomical Pathology, Faculty of Medicine, Universitas Sumatera Medan, Indonesia royherbonsinambela82@yahoo.com

Background: Thyroid carcinoma is a malignancy of the thyroid gland originating from follicular cells or thyroid parafolicles. Consists of Papillary thyroid carcinoma (PTC) and Follicular thyroid carcinoma (FTC). The incidence of thyroid cancer is greatly influenced by age, sex, geography, and other factors.

Methods: This study was a descriptive study with a cross-sectional approach. There were 104 samples of thyroid carcinoma diagnosed histopathologically as PTC and FTC from paraffin block at RSUP H. Adam Malik Medan in 2015-2019. Data regarding age, sex, clinical stage were obtained from medical records. Slaid reviews were performed and lymphovascular invasion (LVI), tumor-infiltrating lymphocytes (TILs), and histopathologic subtypes were determined.

Results: From 104 samples, PTC and FTC were found mostly in the 45-59 years age group where 32 samples of PTC and 20 samples of FTC. Mostly found in the female sex, where the PTC 61 samples and 21 samples of FTC. The most clinical stage was found at stage I where PTC T3 was 66 samples, N0 65 samples, M0 80 samples while FTC T3 18 samples, N0 23 samples, M0 24 samples. In a total of 57 samples of PTC, LVI was negative, while 21 samples were FTC, LVI was positive. TILs in PTC were found to have a minimum number of 53 samples and FTC with the highest number of 14 samples. The most subtypes are classic PTC with 54 samples and FTC widely invasive in 19 samples.

Keywords: papillary thyroid carcinoma, follicular thyroid carcinoma

\section{INTRODUCTION}

Thyroid carcinoma is a malignancy of the thyroid gland that originates from the follicular cells or thyroid parafollicular. This carcinoma is relatively rare, which is only about $1 \%$ of all malignancies in the whole body. 1 The reported incidence of thyroid carcinoma is 2.3 per 100,000 women and 0.9 per 100,000 men in 900 new cases and 250 deaths recorded in the UK and Wales. 2 In Indonesia, thyroid carcinoma ranks 9th out of 10 most malignancies in 2010.3 Thyroid carcinoma has slow growth and course of the disease, as well as low morbidity and mortality. A small proportion is fast-growing and very malignant with a poor prognosis. In geographical conditions in coastal areas where iodine consumption is sufficient or sometimes excess, PTC is found. In the mountains or highlands where iodine consumption is less, FTC is more dominant. ${ }^{3,4}$

Thyroid carcinoma is diagnosed in the third to sixth decades of life. It affects women more often than men.4 The median age of PTC at diagnosis is 50 years. 1 In FTC, it usually occurs in adults and children rarely.6,8 The risk of recurrence and death increases with age, especially after age 40 years. and under 10 years of age. ${ }^{2}$

LVI is an independent predictor of lymph node metastasis and for survival.7 LVI is defined as carcinoma cells present in endothelial (lymphatic or blood vessel) restricted spaces. Tumor-infiltrating lymphocytes (TILs) consist of a variety of different lymphocytes, which include CD4 + T cells, CD8 + T cells, $\gamma \delta$ T cells, B cells, NK cells, and NKT cells. Research has shown that not only $\alpha \beta$ CD4 + and CD8 + T cells have an important role in causing positive or negative effects in regulating anti-tumor immunity, but also other groups of lymphocytes. TILs are the migration of lymphocytes into the tumor or peritumoral cells. Lymphoid cells in neoplastic tissue have a link between inflammation and malignancy.

\section{MATERIALS AND METHODS}

In this study, 104 samples of PTC and FTC who underwent surgery at H. Adam Malik General Hospital Medan in 2015-2019 were diagnosed histopathologically with Hematoxylin Eosin (H\&E) staining. The study was 
conducted based on age, sex, clinical stage, lymphovascular invasion, tumor-infiltrating lymphocytes, and subtypes in FTC and PTC.

\section{RESULTS}

In this study, it is known that the mean age of patients is 49.35 years old with a minimum of 11 years, a maximum of 77 years, and a standard deviation of 13.89 years. In PTC patients based on the age group the most at $45-59$ years, 32 cases $(30.2 \%)$, and the least $\leq 14$ years 2 cases $(1.9 \%)$, age $\geq 60$ years 21 cases $(20.2 \%)$, aged $30-44$ years 18 cases $(17.3 \%)$, the rest were found at age 15-29 years 6 cases (5.8\%). There were no cases of FTC sufferers based on the age group of 45-59 years, namely 20 cases $(19.2 \%)$, in the age group $\leq 14$ and $15-29$ years, there were no cases of FTC sufferers, $\geq 60$ years 3 cases $(2.9 \%)$, the rest were found at the age of $15-59$ years 62 cases $(1.9 \%)$. (Table 1)

Table 1. Distribusi of PTC and FTC patients based on patient age.

\begin{tabular}{llllll}
\hline Age $($ year $)$ & PTC & & FTC & Total \\
\cline { 2 - 5 } & $(\mathrm{n})$ & $(\%)$ & $(\mathrm{n})$ & $(\%)$ & \\
\hline$\leq 14$ & 2 & 1,9 & 0 & 0 & 6 \\
$15-29$ & 6 & 5,8 & 0 & 0 & 20 \\
$30-44$ & 18 & 17.3 & 2 & 1.9 & 52 \\
$45-59$ & 32 & 30.8 & 20 & 19.2 & 24 \\
$\geq 60$ & 21 & 20.2 & 3 & 2.9 & 104 \\
\hline Total & 79 & 76 & 25 & 24 & \\
\hline
\end{tabular}

Table 2. Distribution of PTC and FTC patients by sex

\begin{tabular}{llllll}
\hline Sex & PTC & $(\%)$ & FTC & $(\%)$ & Total \\
\hline Male & 19 & 18,3 & 3 & 2,9 & 22 \\
Famale & 61 & 58,6 & 21 & 20,2 & 82 \\
\hline Total & 80 & 76,9 & 24 & 23,1 & 104
\end{tabular}

In this study, it is known that women suffer more from PTC and FTC. In PTC patients there were 61 cases in women while in men 19 cases (18.3\%). FTC in women were 21 cases $(20.2 \%)$ and men only 3 cases $(2.9 \%)$. (Table 2)

Table 3. Distribution of patients with papillary thyroid carcinoma and follicular thyroid carcinoma by clinical stage

\begin{tabular}{cllll}
\hline Stage & PTC & $(\%)$ & FTC & $(\%)$ \\
\hline Tumour (T) & & & & \\
$\bullet \quad$ T1 & 6 & 5,8 & 1 & 0,9 \\
$\bullet \quad$ T2 & 8 & 7,7 & 5 & 4,8 \\
$\bullet \quad$ T3 & 66 & 63,5 & 18 & 17,3 \\
$\bullet \quad$ T4 & 0 & 0 & 0 & 0 \\
Limfe node (N) & & & & \\
$\bullet \quad$ N0 & 65 & 62,5 & 23 & 22,1 \\
$\bullet \quad$ N1 & 15 & 14,4 & 1 & 1 \\
Metastasis (M) & & & & \\
$\bullet \quad$ M0 & 78 & 75 & 24 & 23 \\
$\bullet \quad$ M1 & 2 & 2 & 0 & 0 \\
Stadium & & & & \\
$\bullet \quad$ I & 57 & 54,8 & 6 & 17,3 \\
$\bullet \quad$ II & 24 & 23,1 & 0 & 0,8 \\
$\bullet \quad$ III & 0 & 0 & 0 & 0 \\
$\bullet \quad$ IV & 0 & 0 & & \\
\hline
\end{tabular}


Table 4. Distribution of patients with papillary thyroid carcinoma and follicular thyroid carcinoma by lymphovascular invasion (LVI)

\begin{tabular}{lllllll}
\hline & PTC $(\mathrm{n})$ & $(\%)$ & FTC $(\mathrm{n})$ & $(\%)$ & Total & $(\%)$ \\
\hline LVI (+) & 23 & 22,1 & 24 & 23,1 & 47 & 45,2 \\
LVI (-) & 57 & 54,8 & 0 & 0 & 57 & 54,8 \\
\hline Total & 80 & 76,9 & 24 & 23,1 & 104 & 100
\end{tabular}

In this study, it was found that in PTC and FTC patients, the highest tumor size (T) was 66 cases $(63.5 \%)$, then T2 was 8 cases $(7.7 \%)$ and at least T1 was 6 . cases $(5.8 \%)$ in PTC. Whereas the highest number of FTC was in $\mathrm{T} 3$ as many as 18 cases $(17.3 \%)$, then T2 was 5 cases $(4.8 \%)$ and the lowest in T1 was only 1 case $(0.9 \%)$. In the involvement of lymph (N) in PTC and FTC most at N0. In PTC, the highest number was found in N0 as many as 65 cases $(62.5 \%)$ and $\mathrm{N} 1$ as many as 15 cases $(14.4 \%)$. FTC is also the most in N0 as many as 23 cases $(22.1 \%)$ and N1 only 1 case $(1 \%)$. In addition, it was found that out of 104 people, 16 cases had metastasis to lymph nodes. The majority of PTC and FTC patients do not experience distant metastases. For the stage, there were 57 cases (54.8\%) at stage I and 24 people $(23.1 \%)$ in stage II at PTC while in the FTC there were 17 cases $(16.3 \%)$ at stage I and 6 cases $(5,8 \%)$ at stage II. To determine the stage other than the tumor value (T), nodules $(\mathrm{N})$ and metastases were also determined based on age $<55$ years and $\geq 55$ years. 3 (Table 3 ).

In this study, based on the distribution of sufferers, it was found that the highest number was negative LVI, namely 57 cases $(54.8 \%)$ and 23 cases $(22.1 \%)$ positive LVI in PTC while 24 cases of FTC LVI were positive $(23.1 \%)$. ) and there was no negative LVI (Table 4).

Table 5. Distribution of patients with papillary thyroid carcinoma and follicular thyroid carcinoma by tumor-infiltrating lymphocytes (TILs)

\begin{tabular}{lcccccccc}
\hline Degress TILs & \multicolumn{3}{c}{ Intratumoral TIL } & \multicolumn{5}{c}{ Stromal TILs } \\
\cline { 2 - 9 } & PTC (n) & $\begin{array}{c}\text { FTC } \\
(\mathrm{n})\end{array}$ & Jlh & $\%$ & $\begin{array}{l}\text { PTC } \\
\text { (n) }\end{array}$ & $\begin{array}{l}\text { FTC } \\
(\mathrm{n})\end{array}$ & Jlh & $\%$ \\
\hline $\begin{array}{l}\text { Skor 0 } \\
\text { (no infiltration) }\end{array}$ & 0 & 0 & 0 & 0 & 0 & 0 & 0 & 0 \\
$\begin{array}{l}\text { Skor 1 } \\
\text { (specify } \\
\text { minimum) }\end{array}$ & 53 & 17 & 70 & 67,3 & 31 & 10 & 41 & 39,4 \\
$\begin{array}{l}\text { Skor 2 } \\
\text { (specify medium) }\end{array}$ & 23 & 7 & 30 & 28,9 & 44 & 14 & 58 & 55,8 \\
$\begin{array}{l}\text { Skor 3 } \\
\text { (specify masif) }\end{array}$ & 4 & 0 & 4 & 3,8 & 5 & 0 & 5 & 4,8 \\
\hline Jumlah & 80 & 24 & 104 & 100 & 80 & 24 & 104 & 100 \\
\hline
\end{tabular}

In this study, out of 104 cases examined PTC and FTC were intratumoral infiltration of TILs. In PTC, which was mostly found with a minimum title, it was found in 53 cases $(51 \%)$, a moderate rate was found in 23 cases $(22.1 \%)$ and a massive mention was found in 4 cases $(3.9 \%)$. In FTC, it was found more in a minimum of 17 cases $(16.3 \%), 7$ cases moderate $(6.7 \%)$ and there was no massive mention. Infiltration of stromal TILs in PTC and FTC. In PTC, which was mostly found in a moderate number of 44 cases (42.3\%), a minimum of 31 cases (29.8\%), and massive 5 cases $(4.8 \%)$. Whereas in the FTC the most were 14 cases $(13.5 \%)$, there were at least 10 cases (9.6\%), while the massive ones were not found. In the PTC and the FTC, there were none that were not mentioned. (Table 5) 
Table 6. Distribution of patients with papillary thyroid carcinoma and follicular thyroid carcinoma by histopathological type

\begin{tabular}{|c|c|c|c|}
\hline Tipe histopatologi & & Total (n) & Persentase $(\%)$ \\
\hline \multicolumn{4}{|l|}{ Papillary thyroid carcinoma } \\
\hline - $\quad$ PTC klasik & & 54 & 51,9 \\
\hline - Papillary microcarcinoma & & 0 & 0 \\
\hline - Follicular variant of PTC & & 23 & 22,1 \\
\hline - Encapsulated variant & & 0 & 0 \\
\hline - Diffuse sclerosing variant & & 0 & 0 \\
\hline - Tall cell variant & & 0 & 0 \\
\hline - Columnar cell variant & & 2 & 1,9 \\
\hline - Cribriform-morular variant & & 0 & 0 \\
\hline - Hobnail variant & & 0 & 0 \\
\hline $\begin{array}{l}\text { - Papillary thyroid carcinoma } \\
\text { fibromatosis/fasciitis-like stroma }\end{array}$ & with & 0 & 0 \\
\hline - Solid/trabecular variant & & 0 & 0 \\
\hline - Oncocytic variant & & 1 & 1,0 \\
\hline - $\quad$ Spindel cell variant & & 0 & 0 \\
\hline - Clear cell variant & & 0 & 0 \\
\hline - Warthin-like variant & & 0 & 0 \\
\hline \multicolumn{4}{|l|}{ Follicular thyroid carcinoma } \\
\hline - Minimaly invasive & & 4 & 3,8 \\
\hline - Encapsulated angioinvasive & & 1 & 1,0 \\
\hline - Widely invasive & & 19 & 18,3 \\
\hline \multicolumn{2}{|l|}{ Total } & 104 & 100 \\
\hline
\end{tabular}

In this study, it is known that as many as 80 people (76.9\%) were diagnosed as PTC where there were 54 cases $(51.9 \%)$ with classic PTC, 23 cases $(22.1 \%)$ follicular variant of PTC, 2 cases $(1,9 \%)$ columnar variant and 1 case $(1 \%)$ oncocytic variant. While the remaining 24 cases $(23.1 \%)$ were diagnosed as FTC. Mostly found in widely invasive 19 cases $(18.3 \%)$ then minimally invasive 4 cases $(3.8 \%)$ and the least Encapsulated angioinvasive 1 case $(1.0 \%)$. 

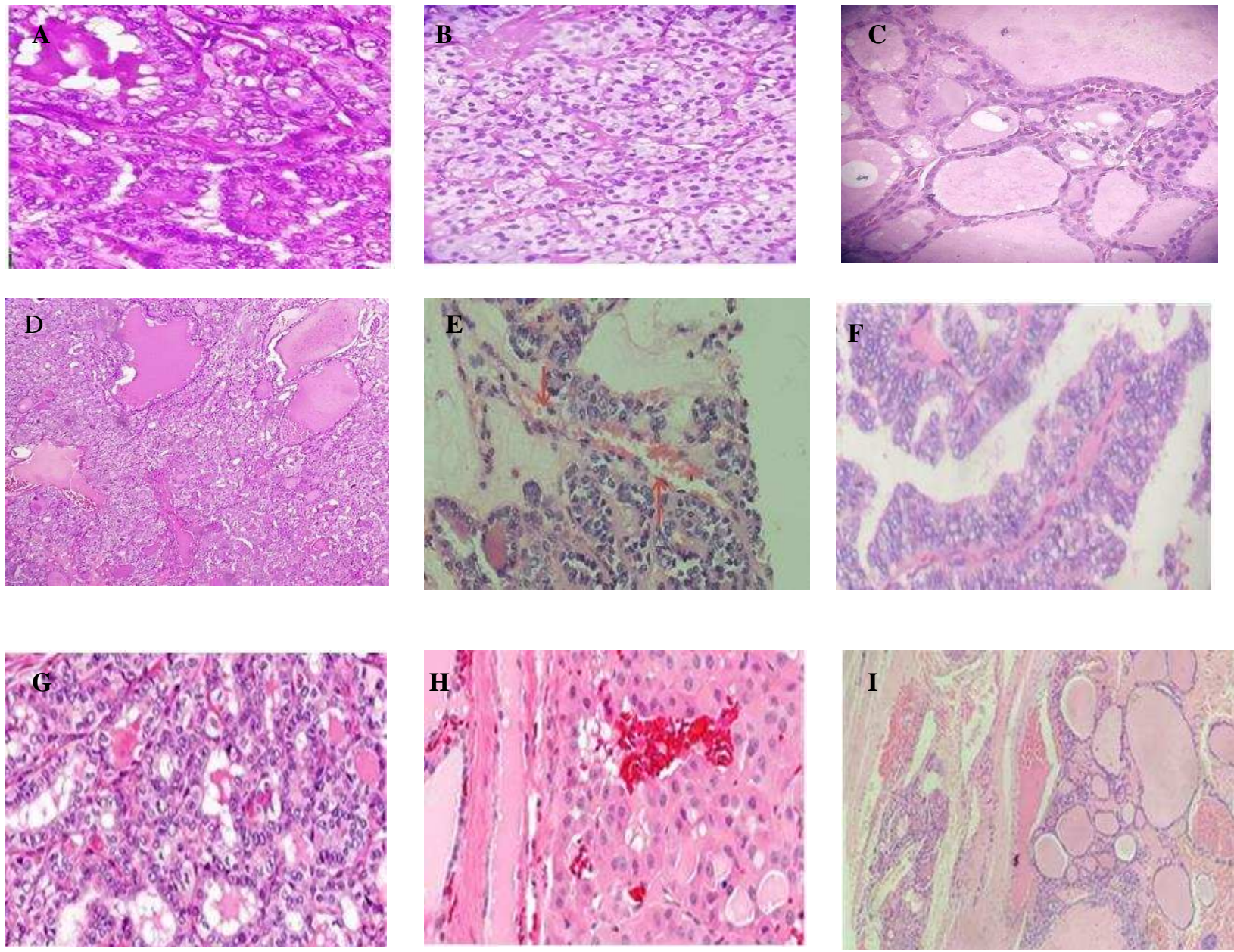

Figure 1. TILs 400x H\&E A. Intratumoral TILs score 1, B. Intratumoral TILs score 3, C. Stromal TILs score 1, D. Stromal TILs score 3, E. Lymphovascular invasion 40x H\&E, F. Papillary thyroid carcinoma classic 100x H\&E, G. PTC variant Oncocytic 100x H\&E, H. PTC variant follicular 100x H\&E, I. Follicular thyroid carcinoma.

\section{DICUSSION}

The number of patients diagnosed histopathologically with PTC and FTC thyroid carcinoma at H. Adam Malik General Hospital Medan in 2015-2019 was 104 samples. Based on the number of cases of thyroid carcinoma, there is an increase in the number of cases. In this study, it was found that the mean of patients was $49.35 \pm$ SD 13.89 years. In addition, most PTC and FTC patients were mostly found in the 45-59 years age group. In PTC, there were 32 patients $(30.8 \%)$ while FTC was 20 patients $(19.2 \%)$. This is in accordance with Fitriyani's research which stated that most thyroid carcinoma patients were 45-59 years old (43.2\%). However, the results of this study contradict Polyzos and Ye et al. Polyzos found that $22.2 \%$ of the thyroid carcinoma patients were $\geq 70$ years old and the patients were at least 50-59 years old (5.9\%). Ye et al stated that most thyroid carcinoma patients were between $30-44$ years old $(n=449$ patients, $43.8 \%)$. However, the high incidence of tumors in the 45-60 year age group $(\mathrm{n}=$ 370 patients, $36.1 \%$ ) should not be neglected.10 The increasing age-related incidence is still not fully understood, at least partly due to the advancement of diagnostic methods such as ultrasound, scan thyroid, fine needle biopsy (Sibajah), and increased cancer recognition.

In this study, it is known that women suffer more from PTC and FTC. In PTC, there were 61 women (58.6\%) and 19 men (18.3\%). Most FTC women 21 people (20.2\%) and only 3 men (2.9\%). This is consistent with research by Fitriyani and Ye et al.9,10 Ye et al also found that the malignancy rate was significantly increased in female patients $(82.3 \%)(\mathrm{p}=0.014) .10$ However, this is different from the Polyzos study. which states that male 
patients have a significantly higher rate of malignancy $(28.3 \%)$ than female patients $(6.8 \%, \mathrm{p}<0.001) .11$ The presence of female dominance indicates that hormonal factors are involved. Several studies have shown that biological changes that occur during pregnancy can increase the risk of thyroid cancer.12 Clinical stage of thyroid carcinoma based on the TNM system according to WHO is seen from tumor size (T), the involvement of lymph nodes $(\mathrm{N})$, and the presence or absence of metastases $(\mathrm{M})$ ( Table 4.3) and it was found that most patients had T3 in PTC 66 people $(63.5 \%)$, FTC 23 people $(22.1 \%)$ and M0 $(75 \%)$ in PTC while FTC $23 \%$. In addition, from the results of this study, it was found that out of 104 people, only 16 people had their KGB checked. Of the 16 people, only 2 were known to have KGB enlargement level II (1.9\%), while the rest did not know which KGB was taken and examined. Ort and Goldenberg stated that central lymph node involvement was more common in paratracheal $(43 \%)$ and ipsilateral paratracheal (36\%). If on the lateral side, mid-lower level or levels III to IV (38\%) were more common. Lateral skip metastasis can occur.13 Most of the PTC and FTC patients $(\mathrm{n}=102$ people, 98.1\%) did not experience distant metastases and only 2 people (1.9\%) had distant metastases, namely to the lungs. When viewed further, those who experienced distant metastases were both diagnosed with PTC and one was female, while the other was male.

PTC (76.9\%), was found to be more than the FTC (23.1\%). This is in accordance with the research of Fiore and Vitti, Ye et al. Fitriyani stated that most cases of thyroid malignancy are PTC. The increased incidence of PTC is probably related to the increasing prevalence of early detection methods through ultrasound examination and Sibajah. Another reason is the recognition of the characteristic core changes to morphological criteria for PTC.14 Some literature suggests that FTC usually occurs in adults and rarely in children.5,6 In this study, it was found in the $\leq 14$ year age group, 15-29 years of age diagnosed as PTC. Of 18 patients aged 30-34 years diagnosed with PTC and 2 people (1.9\%) FTC. Of the 52 patients aged 45-59 years, 33 were diagnosed with PTC, and 19 (18.3\%) FTC. Of the 24 patients aged $>60$ years, 21 were diagnosed with PTC, and $3(2.9 \%)$ FTC. The results of this study are in line with the research conducted by Parura et al. Which states that FTC is not found in patients aged $<20$ years, while the age variation of PTC patients is very wide. In this study, it was found that the youngest patient's age was 11 years in the age group of $\leq 14$ years.

Of the 104 patients, 19 male patients were diagnosed with PTC, and 61 (58.7\%) female patients, 24 (23.1\%) diagnosed with FTC. Ponniah et al stated that the highest incidence of PTC was found in women. The existence of early menarche, young parous with recent pregnancies, all of them increase the risk of developing PTC. 15 In this study, 57 patients did not experience LVI while there was no FTC negative LVI. 23 patients (22.1\%) had LVI positive for PTC and 24 (23.1\%) LVI on FTC. This result is in accordance with the research of Leni et al, which states that the number of LVI negative patients is more than LVI positive with 63 LVI (+) patients and 615 LVI (-) patients.

Infiltrating lymphocytes in thyroid carcinoma has not been studied before. In this study, researchers observed the infiltration of intratumoral and peritumoral TILs (stromal TILs). Attempts to assess intratumoral TILs are warranted because these inflammatory cells show direct interaction with tumor cells. It is known that PTC is more often found with a minimum of 53 cases $(51 \%)$. At least 17 cases were found in FTC (16.3\%). In the stromal TILs, as many as 44 cases $(42.3 \%)$ said it was moderate in PTC while in the FTC the most cases were also as many as 14 cases $(13.5 \%)$. There is not much literature that evaluates intratumoral TILs and stromal TILs in thyroid carcinoma, so we cannot compare the results of this study with the literature. In this study, it is known that as many as 80 people (76.9\%) were diagnosed as PTC where there were 54 people $(51.9 \%)$ with classic PTC and 24 people (23.1\%) were diagnosed as FTC where the most were found widely invasive 19 people $(18.3 \%)$. This is in accordance with Fitriyani's research which stated that PTC patients were more numerous than FTC.

\section{CONCLUSION}

After conducting research on PTC and FTC patients at H. Adam Malik General Hospital Medan in 20152019, it can be concluded that PTC and FTC patients are mostly in the 45-59 years age group. Based on the sex, PTC and FTC sufferers are more common in women Most of the PTC and FTC stage I patients was based on the 2017 WHO classification system for TMN. In PTC, negative LVI was more common, while FTC was not found. FTC was found to be LVI positive, while the PTC was less. Intratumoral infiltration of TILs was mostly found with minimal mention of PTC and FTC. The stromal infiltration of TILs in PTC and FTC was mostly found at moderate 
levels. In the PTC and the FTC, there were none that were not mentioned. Based on the type of histopathology found mostly in classical PTC, FTC is mostly widely invasive.

\section{THANK YOU}

We would like to thank of the Departement of anatomical pathology, Universitas Sumatera Utara and H.Adam Malik General Hospital, Medan, Indonesia for their help and cooperation.

\section{ETHICAL APPROVAL}

Health Research Ethical Committee. Universitas Sumatera Utara, Medan, Indonesia approved this study.

\section{AUTHORS DETAILS}

First Author- dr. Roy Herbon Sinambela, resident of Anatomical Pathology Departement, Faculty of Medicine, Universitas Sumatera Utara, Medan, Indonesia.

Second Author- Dr.dr.Lidya Imelda Laksmi, M.Ked(PA), Sp.PA, Lecture and staff anatomical Pathology Departement, Faculty of Medicine, Universitas Sumatera Utara, Medan Indonesia.

Third Author- dr. Joko S Lukito, Sp.PA(K), Lecture and staff anatomical Pathology Departement, Faculty of Medicine, Universitas Sumatera Utara, Medan Indonesia

Fourth Author- Dr.dr.H.Delyuzar, M.Ked(PA), Sp.PA(K), Lecture and staff anatomical Pathology Departement, Faculty of Medicine, Universitas Sumatera Utara, Medan Indonesia.

Fifth author- Dr.dr. T.Ibnu Alferraly, M.Ked(PA), Sp.PA D.Bioeth, Lecture and staff anatomical Pathology Departement, Faculty of Medicine, Universitas Sumatera Utara, Medan Indonesia.

Corresponding Author- Roy Herbon Sinambela, resident of Anatomical Pathology Departement, Faculty of Medicine, Universitas Sumatera Utara, Jl. Universitas no.1 Gedung Abdul Hakim, Keruntung, Medan Indonesia.

Emai ID: royherbonsinambela82@yahoo.com

\section{REFERENCES}

1. Kementerian Kesehatan RI Pusat Data dan Informasi. Info Datin Pusat Data dan Informasi Kementerian Kesehatan RI. 2015.

2. British Thyroid Association, Royal College of Physicians. Guidelines for the Management of Thyroid Cancer, 2nd Edition. Report of Thyroid Cancer Guideines Update Group. London: Royal College of Physicians; 2007. P. 1. doi:10.1089/thy.2015.0020.

3. Lloyd R.V, Osamura R.Y, Kloppel G, Rosai J. WHO Classification of Tumours of Endocrine Organs. (4th edition). IARC:Lyon. 2017; pp. 81-95.

4. Putri E, Khambri D, Rusjdi SR, Artikel Penelitian Hubungan Daerah Tempat Tinggal dengan Gambaran Histopatologi Karsinoma Tiroid pada masyarakat Sumatera Barat Kesehatan Andalas. 2007;36(21):pp.171

5. Agur Anne M.R, Dalley, Arthur F, Grant's Atlas of Anatomy, 12th edition, 2015;pp.770

6. Ruggeri RM, Campenni A, Baldari S, Trimarchi F, Trovato M. What is new on thyroid cancer biomarkers. Biomark Insights. 2008;pp.237-52

7. Seng Y, Shin S, The Role of Lymphovascular Invasion as a Prognostic Factor in patients with Lymph Node-Positive : 198-203.

8. Kreike B, van Kouwenhove M, Horlings H, Weigelt B, Peterse H, Bartelink H. Gene expression profiling and histopathological characterization of triple-negative/basal-like breast carcinomas. Breast Cancer Res. 2007; 9(5)

9. Fitriyani H, Alferraly TI, Laksmi LI. Correlation between TSH, T3, T4 and Histological Types of Thyroid Carcinoma. Indonesian Journal of Clinical Pathology and Medical Laboratory. 2018; 24(3): 201-4.

10. Ye ZQ, Gu DN, Hu HY, Zhou YL, Hu XQ, Zhang XH. Hashimoto's Thyroiditis, Microcalcification and Raised Thyrotropin Levels within Normal Range are Associated with Thyroid Cancer. World Journal of Surgical Oncology. 2013; 11: 56. 
11. Polyzos SA, Kita M, Efstathiadou Z, Poulakos P, Slavakis A, Sofianou D, et al. Serum Thyrotropin Concentration as a Biochemical Predictor of Thyroid Malignancy in Patients Presenting with Thyroid Nodules. J Cancer Res ClinOncol. 2008; 134: 953-60. doi: 10.1007/s00432-008-0373-7.

12. Dewi IGAMP, Adiputra PAT. Karakteristik Penderita Kanker Tiroid di Bagian Bedah Onkologi RSUP Sanglah Denpasar Tahun 2009-2012. E-jurnal Medika Udayana. 2015; 4(3). ISSN 2303-1395.

13. Ort S, Goldenberg D. Management of Regional Metastases in Well- Differentiated Thyroid Cancer. Otolaryngol Clin N Am. 2008; 41:1207-18

14. Sadow PM, Faquin WC. Poorly differentiated thyroid carcinoma: an incubating entity. Frontiers in Endocrinology 3:77. doi: 10.3389/fendo.2012.00077.

15. Ponniah A. Papillary Carcinoma Thyroid- A 11 year Epidemiological Study with Histopathological Correlation in a Tertiary Care Centre in South Malabar Region in Kerala, India. Journal of Pathology of Nepal. 2015;5:798- 805.

16. Ieni A, Barresi V, Cardia R, Licata L, Di Bari F, Benvenga S, et al. The micropapillary/hobnail variant of papillary thyroid carcinoma: A review of series described in the literature compared to a series from one southern Italy pathology institution. Rev Endocr Metab Disord 2016 Nov 28. 